\title{
Hydrogen sulfide causes excision of a genomic island in Pseudomonas syringae pv. phaseolicola
}

\author{
H. Neale • N. Deshappriya • D. Arnold • M. E. Wood • \\ M. Whiteman • J. T. Hancock
}

Accepted: 19 April 2017 / Published online: 16 May 2017

(C) The Author(s) 2017. This article is an open access publication

\begin{abstract}
Hydrogen sulfide $\left(\mathrm{H}_{2} \mathrm{~S}\right)$ is known to be an important signalling molecule in both animals and plants, despite its toxic nature. In plants it has been seen to control stomatal apertures, so altering the ability of bacteria to invade plant tissues. Bacteria are known to generate $\mathrm{H}_{2} \mathrm{~S}$ as well as being exposed to plantgenerated $\mathrm{H}_{2} \mathrm{~S}$. During their interaction with plants pathogenic bacteria are known to undergo alterations to their genomic complement. For example Pseudomonas syringae pv. phaseolicola (Pph) strain 1302A undergoes loss of a section of DNA known as a genomic island (PPHGI-1) when exposed to the plants resistance response. Loss of PPHGI-1 from Pph 1302A enables the pathogen to overcome the plants resistance response and cause disease. Here, with the use of $\mathrm{H}_{2} \mathrm{~S}$ donor molecules, changes induced in Pph 1302A genome, as demonstrated by excision of PPHGI-1, were investigated. Pph 1302A cells were found to be resistant to low
\end{abstract}

H. Neale · D. Arnold · J. T. Hancock $(\bowtie)$

Faculty of Health and Applied Sciences, University of the West of England, Coldharbour Lane, Bristol BS16 1QY, UK

e-mail: john.hancock@uwe.ac.uk

\section{N. Deshappriya}

Department of Botany, University of Kelaniya, Kelaniya, Sri Lanka

\section{E. Wood}

Biosciences, University of Exeter, Exeter, UK

\section{Whiteman}

University of Exeter Medical School, University of Exeter, Exeter, UK concentrations of $\mathrm{H}_{2} \mathrm{~S}$. However, at sub-lethal $\mathrm{H}_{2} \mathrm{~S}$ concentrations an increase in the expression of the PPHGI-1 encoded integrase gene (xerC), which is responsible for island excision, and a subsequent increase in the presence of the circular form of PPHGI-1 were detected. This suggests that $\mathrm{H}_{2} \mathrm{~S}$ is able to initiate excision of PPHGI-1 from the Pph genome. Therefore, $\mathrm{H}_{2} \mathrm{~S}$ that may emanate from the plant has an effect on the genome structure of invading bacteria and their ability to cause disease in plants. Modulation of such plant signals may be a way to increase plant defence responses for crops in the future.

Keywords Circular intermediate - Genomic island . Hydrogen sulfide $\cdot$ Plant defence $\cdot$ Plant pathogen interactions $\cdot x e r C$

\section{Introduction}

Hydrogen sulfide $\left(\mathrm{H}_{2} \mathrm{~S}\right)$ is found widely in the environment, being generated in soils and marshes (Morse et al. 1987), and produced by human activity (Guidotti 1996). It is also produced by underwater thermal vents (Martin et al. 2008), indicating that organisms have had to tolerate it during millions of years of evolution, during which time this toxic compound has been adopted as a signalling molecule in cells (Wang 2002, 2003). Of particular relevance here, it has been known for some time that $\mathrm{H}_{2} \mathrm{~S}$ is produced by bacteria (Clarke 1953) and plants (Calderwood and Kopriva 2014). 
$\mathrm{H}_{2} \mathrm{~S}$ is inherently toxic, for example, being a known inhibitor of Complex IV of mitochondria, hence reducing ATP production (Dorman et al. 2002). However, more recently it has been found to be an important component of cell signalling pathways in both plants and animals, and has been dubbed as a third gasotransmitter (Wang 2002, 2003) in addition to nitric oxide and carbon monoxide. In plants, $\mathrm{H}_{2} \mathrm{~S}$ is part of important sulfur metabolism suggesting that there are at least low levels in cells all of the time (Calderwood and Kopriva 2014). Dedicated enzymes in plants generate $\mathrm{H}_{2} \mathrm{~S}$, such as desulhydrases (Alvarez et al. 2010). The effects in plants include increased germination rates (Dooley et al. 2013), alteration of glutathione levels (de Kok et al. 1985) and mediating the responses to a range of stresses (reviewed by Lisjak et al. 2013). It has been reported that $\mathrm{H}_{2} \mathrm{~S}$ causes the opening of stomata on plants (Lisjak et al. 2010, 2011), although closure induced by $\mathrm{H}_{2} \mathrm{~S}$ has also been reported (García-Mata and Lamattina 2010), the difference probably due to the plant growth conditions. Either way, modulation of the opening of stomata will affect the ability of bacteria to invade plants, altering the plant-pathogen dynamics. Therefore, the action of $\mathrm{H}_{2} \mathrm{~S}$ is important to consider in plant-bacterial interactions.

When bacteria invade a plant it has been found that their genomic complement is not static, but is altered by the conditions governed by the plant (Lovell et al. 2011). Bacteria such as Pseudomonas syringae carry mobile genetics elements known as genomic islands (GIs). GIs are large mobilisable fragments of DNA that are part of the flexible bacterial gene pool, which is comprised of transposons, integrons, genomic islets $(<10 \mathrm{~kb})$, and GIs (>10 kb: Hacker and Carniel 2001). GIs are usually between 10 and 200 kilobases in length, differ from the genome in their GC content and frequently harbour phage and/or plasmid derived sequences that include transfer genes and integrases responsible for mobilisation (Juhas et al. 2009).

The outcome of invasion of the bacteria on the plant is determined by gene-for-gene relationships (Taylor et al. 1996). In this, if the bacteria expresses an effector protein recognised by the host-plant resistance protein, then the hypersensitive response (HR) is triggered and the plant defends itself against the ingress of the bacteria. On the other hand, if the plant lacks the resistance gene disease may result. Therefore, the presence of this effector gene in the bacteria genome determines if bacteria has the capability of causing disease on certain plants, or whether the plant mounts a successful resistance response.

Pseudomonas syringae pv. phaseolicola (Pph) causes halo blight disease on common bean. The symptoms are characterised by the appearance of watersoaked lesions on leaves, pods and stems. These lesions develop into greenish-yellow haloes on leaves. Seeds may also be affected, sometimes showing wrinkled or buttery-yellow patches on the seed coat.

Pph1302A contains a 106 kb GI, PPHGI-1, on which is encoded an effector gene, $a v r P p h B$ (also known as hopAR1) (Pitman et al. 2005). If the bacteria containing PPHGI-1 infects the bean $P$. vulgaris cultivar Tendergreen, which contains the $R 3$ resistance gene then the HR in the plant is triggered. However on exposure to the HR, PPHGI-1 can be excised from the bacterial chromosome, forms a circular molecule and is then lost from the bacterial cell. This results in the loss of the effector gene $\operatorname{avrPphB}$, so enabling the resultant bacteria to cause disease in plants in which a HR would have resulted before. Pitman et al. (2005) further demonstrated that the integrase gene $\operatorname{xerC}$ (PPHGI-1 ORF.100) is required for GI excision and that $x e r C$ transcriptional expression is greatly increased (50 times) in leaves undergoing the HR compared to in vitro conditions. Furthermore, Lovell et al. (2009, 2011) demonstrated that PPHGI-1 can be transferred between strains of $P p h$ via natural transformation and is able to integrate into the recipient strains chromosome.

Using PPHGI-1 as an example shows that factors produced by the plant host can have a profound effect on the way the bacteria respond to their environment and cause disease in the plant. Furthermore, the intraplant environment the bacteria encounters on invasion is not static (O'Leary et al. 2016). The apoplast, the space between the cells the bacteria will first invade, is rich in a variety of components. For example, the abundance of nutrients in the apoplast has been studied (Rico and Preston 2008) as well as the protein complement (Petriccione et al. 2014). However, the constituents of the apoplast are not fixed. It was recently shown that leaf apoplastic fluid is altered during the first $6 \mathrm{~h}$ following the initiation of a bacteria-plant interaction (O'Leary et al. 2016), while the presence of proteins can alter over a period of days (Petriccione et al. 2014). The complement of the apoplastic fluid may contain many signalling molecules such as reactive oxygen species (ROS) and gasotransmitters. Of importance here is that the hydrogen sulfide $\left(\mathrm{H}_{2} \mathrm{~S}\right)$ produced by plants is not 
confined to the cells but can be measured when released (Wilson et al. 1978), and therefore there is likely exposure of invading bacteria to plant-derived $\mathrm{H}_{2} \mathrm{~S}$.

Here, we investigate whether exposure to $\mathrm{H}_{2} \mathrm{~S}$ has an effect on the Pph 1302A genome by exposing the bacteria to $\mathrm{H}_{2} \mathrm{~S}$ donor molecules and measuring the expression of the integrase $\operatorname{xer} C$ and the subsequent formation of the PPHGI-1 circular intermediate, produced following excision of the GI from the chromosome. It was found that sub-lethal concentrations of $\mathrm{H}_{2} \mathrm{~S}$ donors led to an increase in PPHGI-1 excision. Such data will be informative of whether such signalling molecules from the plant can influence the onset or progression of bacterial disease in plants.

\section{Materials and methods}

Bacterial growth conditions

Pph strain 1302A was cultured at $25{ }^{\circ} \mathrm{C}$ for $48 \mathrm{~h}$ on King's B (KB) agar plates (Difco, UK). Broth cultures were grown in Luria Bertani media (LB, Difco, UK) overnight at $25{ }^{\circ} \mathrm{C}$.

Growth assays

For in vitro growth rates, three replicates of $P p h$ 1302A were grown overnight in LB broth and diluted to $8 \times 10^{8}$ $\mathrm{CFU} / \mathrm{ml}\left(\mathrm{OD}_{600} 1.0\right)$. Cells $(1 \mathrm{ml})$ were sub-cultured into $9 \mathrm{ml}$ fresh LB broth and the optical density measured and recorded. Cultures were incubated at $25{ }^{\circ} \mathrm{C}$ with shaking $(10 \times \mathrm{g})$. After $1 \mathrm{~h}$ the hydrogen sulfide donors, i.e. sodium hydrosulfide $(\mathrm{NaSH})$, sodium sulfide $\left(\mathrm{Na}_{2} \mathrm{~S}\right)$ (both from Sigma Aldrich, UK) and AP39
[ 10 - ox o- 10 - (4-(3-thiox o-3H-1,2-dithiol5yl)phenoxy)decyl) triphenylphosphonium bromide] (Le Trionnaire et al. 2014) were added at final concentrations of $100 \mu \mathrm{M}, 200 \mu \mathrm{M}, 500 \mu \mathrm{M}, 1 \mathrm{mM}, 10 \mathrm{mM}$, $100 \mathrm{mM}$ as appropriate. Optical densities were measured and recorded every hour for a further $8 \mathrm{~h}$.

qPCR

qPCR was used to quantify the expression levels of $x$ er $C$ and the amount of circular intermediate produced in vitro, using the primers as listed in Table 1. Samples were taken at $2 \mathrm{~h}$ and $5 \mathrm{~h}$ post inoculation with the hydrogen sulfide donors. Gene expression was stopped using RNA protect reagent (Qiagen, UK) or DNA lysis solution (Gentra Systems, UK). For quantification of xerC expression, RNA was extracted using the RNAeasy kit (Qiagen, UK) followed by a second DNase step of $15 \mathrm{~min}$ at $37^{\circ} \mathrm{C}$ (Promega, UK). cDNA was synthesised using the TaqMan reverse transcription kit (Qiagen, UK). For circular intermediate quantification, DNA was extracted using the Puregene total DNA extraction kit (Gentra Systems, UK). qPCR was carried out on an ABI 7300 Real-Time PCR System (Applied Biosystems), calibrated with a 7300 Real-Time PCR Systems Spectral Calibration kit (Applied Biosystems). Probes (Table 1) were labelled with 3' FAM and 5' TAMRA TaqMan dyes. The reaction volume of $25 \mu \mathrm{l}$ was composed of $12.5 \mu \mathrm{l}$ TaqMan PCR mastermix (Applied Biosystems), $2 \mu \mathrm{l}$ each primer $(10 \mu \mathrm{M}), 2 \mu \mathrm{l}$ probe $(5 \mu \mathrm{M})$ and $6.5 \mu \mathrm{l}$ RNase free water. Standard qPCR cycling conditions were $50{ }^{\circ} \mathrm{C}$ for $2 \mathrm{~min}, 95^{\circ} \mathrm{C}$ for $10 \mathrm{~min}$ and $40 \times$ cycles of $95^{\circ} \mathrm{C}$ for $15 \mathrm{~s}$, followed by $60{ }^{\circ} \mathrm{C}$ for $1 \mathrm{~min}$.
Table 1 PCR primers used for in this study. * Probes labelled with 5' FAM and 3' TAMRA TaqMan dyes

\begin{tabular}{|c|c|c|}
\hline Primer name & Description & Sequence \\
\hline acpP & Housekeeping gene & $\begin{array}{l}\text { Forward TTGGCGTCAAATCAGAAGAG } \\
\text { Reverse GCTTCTTCGTCAGGGATTTC } \\
\text { Probe *ACCTGGGCGCTGACTCCCTG* }\end{array}$ \\
\hline xerC & $\begin{array}{l}\text { PPHGI-1 bound } \\
\text { xerC integrase }\end{array}$ & $\begin{array}{l}\text { Forward CGACGATACGGCCTCCAA } \\
\text { Reverse AAAGGTGCGGTCGACATCA } \\
\text { Probe *CCCCCTATAGCGGAGCGTCTGGAA* }\end{array}$ \\
\hline QCI & Circular intermediate & $\begin{array}{l}\text { Forward CATGGGCCTTCCAGATTTTC } \\
\text { Reverse CTGCGGTTTGGGATACTGAAC } \\
\text { Probe *CGTAACGCTGAGGCAGGCCCC* }\end{array}$ \\
\hline
\end{tabular}


The X-fold change in gene expression was calculated using untreated WT as calibrator and $a c p P$ as the internal control. Statistically significant differences were determined by ANOVA and Student's t test $(p<0.05)$.

\section{Results}

Three separate donor molecules were used to supply $\mathrm{H}_{2} \mathrm{~S}$ to Pph 1302A and the growth of the bacteria monitored for $8 \mathrm{~h}$. One of the mostly commonly used donors for the supply for $\mathrm{H}_{2} \mathrm{~S}$ is $\mathrm{NaSH}$ (Zhao et al. 2014). The addition of NaSH to Pph 1302A had little effect on growth rate up to a concentration of $1 \mathrm{mM}$ (Fig. 1a). Treatment with $10 \mathrm{mM}$ showed a slight decrease in the growth rate of the cells while $100 \mathrm{mM}$ was toxic, completely inhibiting growth. Another $\mathrm{H}_{2} \mathrm{~S}$ donor with similar kinetics for the release of the gas is $\mathrm{Na}_{2} \mathrm{~S}$. Treatment with this donor had more of a negative effect on cell growth. Some reduction in growth was seen even at a concentration of $10 \mu \mathrm{M}$, with a concentration dependent effect seen up to $10 \mathrm{mM}$, at which total growth inhibition was seen (Fig. 1b). A new $\mathrm{H}_{2} \mathrm{~S}$ donor molecule more recently reported is AP39 (Le Trionnaire et al. 2014; Szczesny et al. 2014). AP39 had little effect on bacterial growth up to $1 \mathrm{mM}$ but at $10 \mathrm{mM}$ growth was completely stopped (Fig. 1c).

One of the responses of bacteria to plant defences is a change in their genetic complement (Arnold et al. 2011), which in the case of Pph 1302A includes the loss of PPHGI-1 (Pitman et al. 2005). Markers of this event include the expression of the integrase $\operatorname{xer} C$ and the subsequent formation of the circular intermediate. Therefore, both of these markers were assessed following treatment of Pph 1302A with $\mathrm{H}_{2} \mathrm{~S}$ donors.

As a measure of the effect of $\mathrm{H}_{2} \mathrm{~S}$ on $P p h$ $1302 \mathrm{~A}$ the expression of the integrase $\operatorname{xer} C$ was measured in vitro following a $2 \mathrm{~h}$ treatment with $\mathrm{H}_{2} \mathrm{~S}$ donors. Treatment with $\mathrm{NaSH}$ gave a concentration dependent increase in xerC expression up to $1 \mathrm{mM}$ (Fig. 2a). Little effect was seen at the lowest concentration tested but there was a rise in expression of $x e r C$ approximately 1.6 fold following treatment with $100 \mu \mathrm{M} \mathrm{NaSH}$, a concentration which did not affect cell growth
(Fig. 1a). Treatment with concentrations of $10 \mathrm{mM}$ or above showed a large reduction in xerC expression (Fig. 2a). Similar results were seen when using $\mathrm{Na}_{2} \mathrm{~S}$ as the $\mathrm{H}_{2} \mathrm{~S}$ source (Fig. 2b), probably due to the increased toxicity of $\mathrm{H}_{2} \mathrm{~S}$ at these concentrations.

With AP39, there was over a 3 fold increase in xerC expression on treatment with $100 \mu \mathrm{M}$ donor after $2 \mathrm{~h}$ (Fig. 2c), a concentration at which this $\mathrm{H}_{2} \mathrm{~S}$ donor had little effect on bacterial growth (Fig. 1c). This rose to nearly 5 -fold with $500 \mu \mathrm{M}$ donor, but higher concentrations showed a reduction of xerC expression compared to the maximal seen, again perhaps because of the detrimental effects of high concentrations of $\mathrm{H}_{2} \mathrm{~S}$ which would be present.

XerC expression leads to the excision of PPHGI from the bacterial chromosome and the subsequent formation of a circular intermediate molecule (Pitman et al. 2005). To confirm further the effects of $\mathrm{H}_{2} \mathrm{~S}$ donors on the $\mathrm{Pph}$ 1302A genome, circular intermediate formation was measured. After $2 \mathrm{~h}$ the production of circular intermediate increased on $\mathrm{H}_{2} \mathrm{~S}$ exposure, using $\mathrm{NaSH}$ as a source of the gas (Fig. 3a). Importantly, at concentrations at which growth rates were not affected, for example $500 \mu \mathrm{M} \mathrm{NaSH}$, the formation of the circulate intermediate was increased by more than 3 fold. Even at very low concentrations, for example $10 \mu \mathrm{M} \mathrm{NaSH}$, there was still a noticeable increase in circulate intermediate formation. A similar situation was seen with the donor $\mathrm{Na}_{2} \mathrm{~S}$. At $10 \mu \mathrm{M}$ there was a 2.5 fold increase in circular intermediate production (Fig. 3b), even though growth of those cells was little affected (Fig. 1b). There was a concentration dependent increase in this affect up to $1 \mathrm{mM}$ after which the production of the intermediate was reduced.

AP39 was found to have similar effects on circular intermediate production after $2 \mathrm{~h}$ (Fig. 3c). A nearly 2fold increase was seen on treatment with $10 \mu \mathrm{M}$ AP39, while a concentration dependent affect was seen up to $500 \mu \mathrm{M}$. As with the other $\mathrm{H}_{2} \mathrm{~S}$ donors, higher concentrations saw a sharp reduction in the presence of the circular intermediate.

With $\mathrm{H}_{2} \mathrm{~S}$ donors such as $\mathrm{NaSH}$ or AP39 there was little effect on cell growth (except at the highest concentrations used) up to $6 \mathrm{~h}$ of treatment. Therefore, the $\operatorname{xer} C$ expression and production of circular intermediates assays were repeated after $5 \mathrm{~h}$ of $\mathrm{H}_{2} \mathrm{~S}$ donor treatments. 
Fig. 1 Growth of Pseudomonas syringae pv. phaseolicola (Pph) $1302 \mathrm{~A}$ in the presence of $\mathrm{H}_{2} \mathrm{~S}$ donors. Pph 1302A was grown overnight in LB broth and diluted to $8 \times 10^{8} \mathrm{CFU} / \mathrm{ml}\left(\mathrm{OD}_{600} 1.0\right)$. Cells $(1 \mathrm{ml})$ were sub-cultured into $9 \mathrm{ml}$ fresh LB broth and the optical density measured and recorded. Cultures were incubated at $25^{\circ} \mathrm{C}$ with shaking (10 xg). After $1 \mathrm{~h}$ the $\mathrm{H}_{2} \mathrm{~S}$ donors were added: a; sodium hydrosulfide (NaSH), b; sodium sulfide $\left(\mathrm{Na}_{2} \mathrm{~S}\right) \mathbf{c} ; \mathrm{AP} 39$, at the concentrations indicated. Optical densities were recorded hourly for 8 h. $n=3$ a

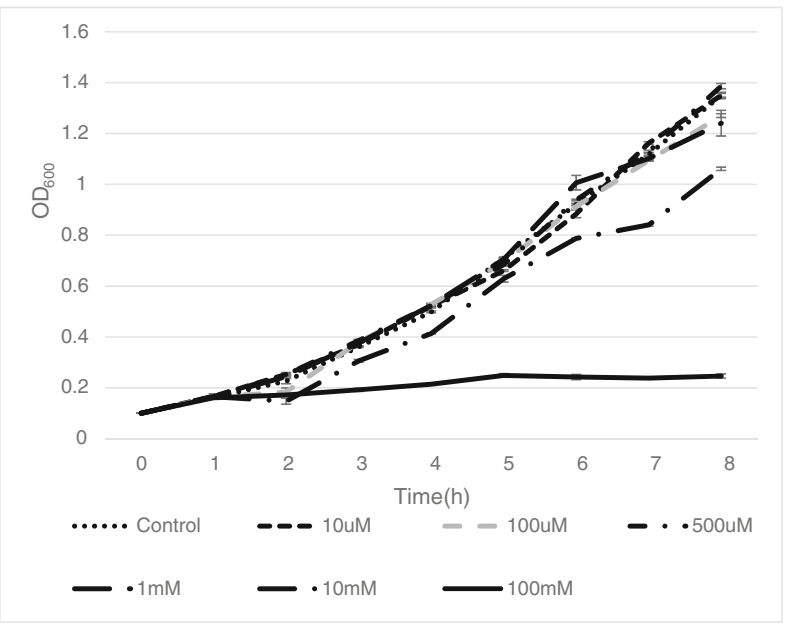

b

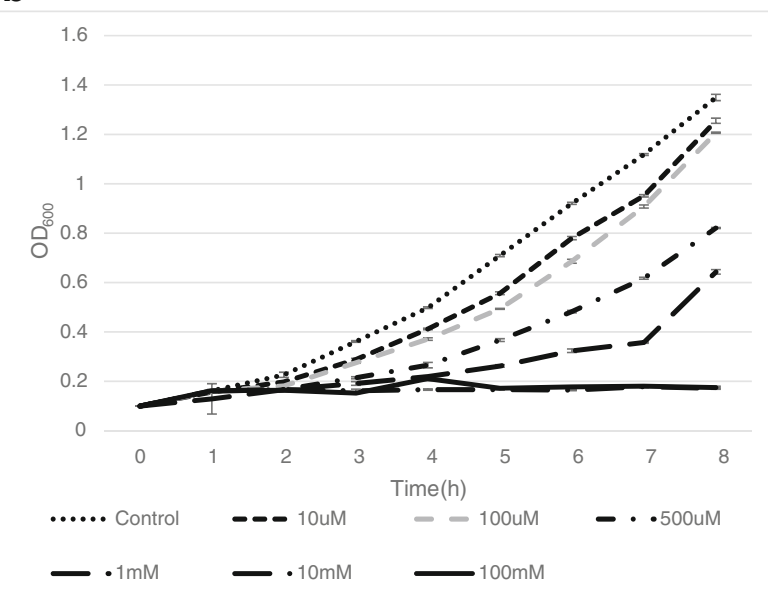

C

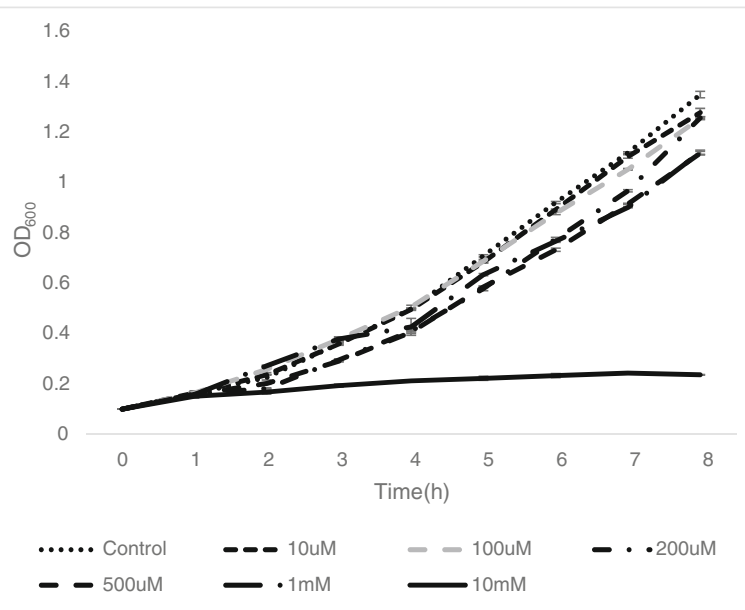


Fig. 2 xerC integrase expression in Pseudomonas syringae pv. phaseolicola (Pph) 1302A treated with $\mathrm{H}_{2} \mathrm{~S}$ donors. Pph 1302A was treated with $\mathrm{H}_{2} \mathrm{~S}$ donors for two hours at the concentrations indicated, after which the expression of $x e r C$ was assayed using qPCR. Results are displayed as X-fold expression. All data were standardized by simultaneous qPCR analysis of acpP expression and error bars represent standard error of the mean of three experimental replicates. *above bars indicate a significant difference compared to the control at $p<0.05$ assessed by ANOVA and Student's t-test. a; sodium hydrosulfide $(\mathrm{NaSH}), \mathbf{b}$; sodium sulfide $\left(\mathrm{Na}_{2} \mathrm{~S}\right)$ c; AP39. $n=3$ a

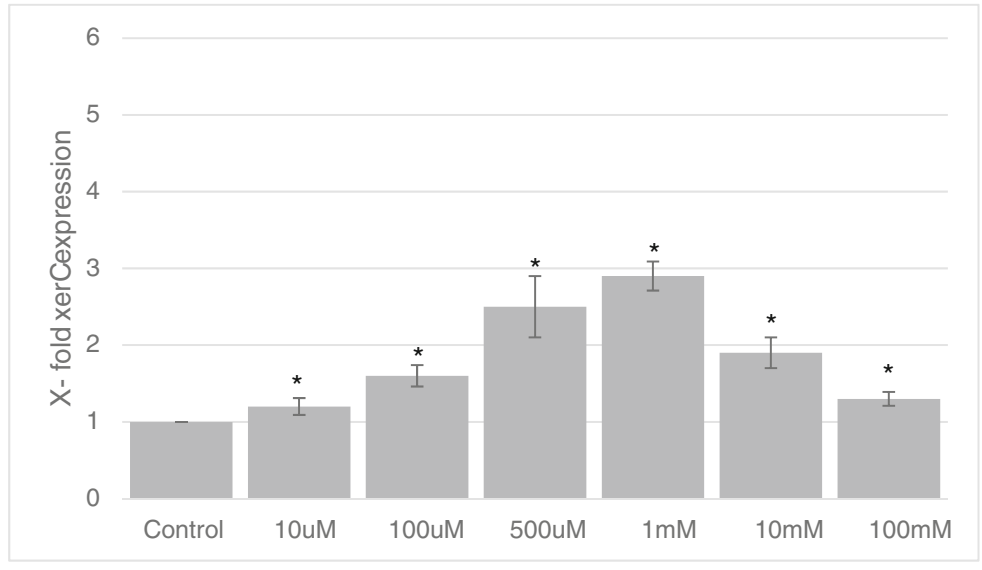

b

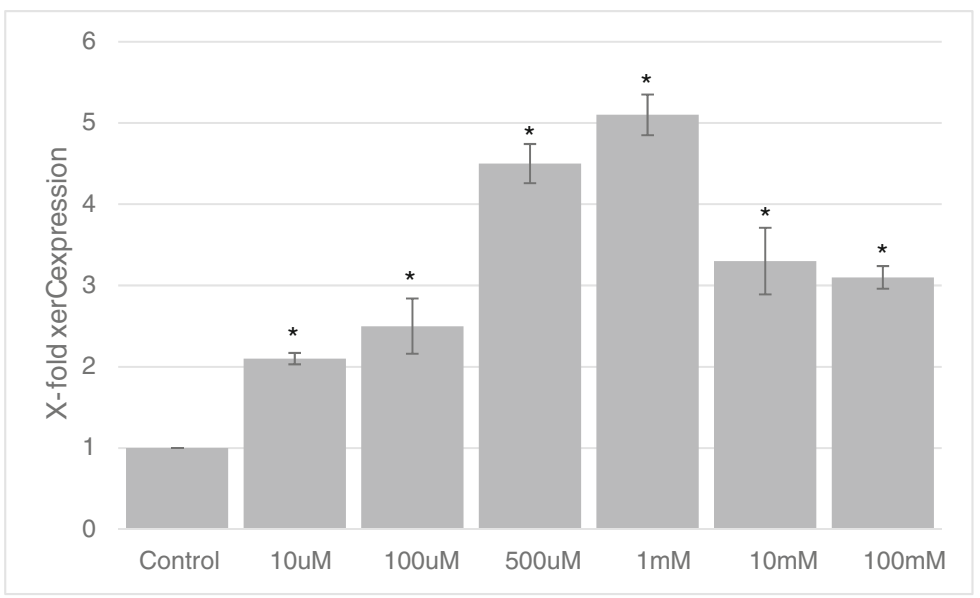

C

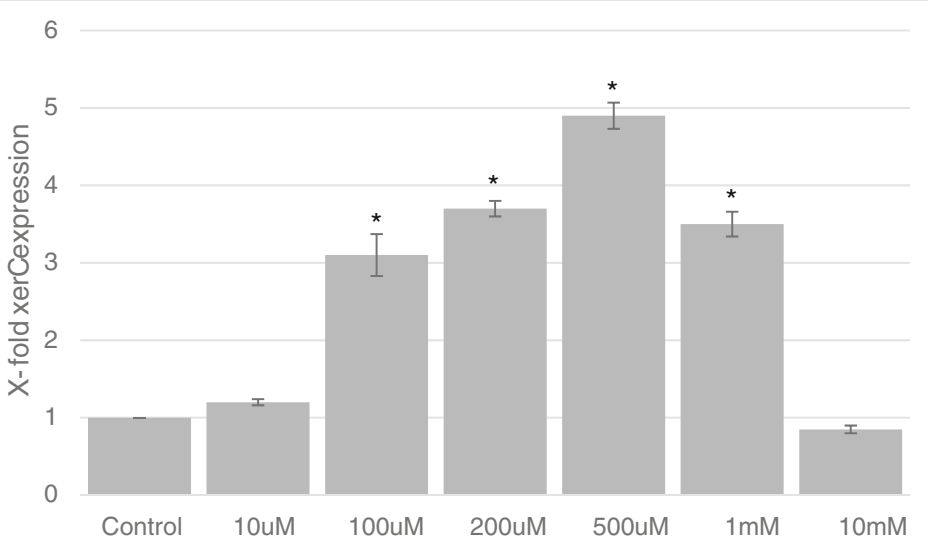

With AP39, there was very little increased effect of the longer treatments. The maximal levels of xerC expression (Fig. 4a) and circular intermediate production (Fig. 4b) were still seen with $500 \mu \mathrm{M}$ and higher 
Fig. 3 Circular intermediate production in Pseudomonas syringae pv. phaseolicola (Pph) 1302A treated with $\mathrm{H}_{2} \mathrm{~S}$ donors. Pph 1302A was treated with $\mathrm{H}_{2} \mathrm{~S}$ donors for two hours at the concentrations indicated, after which the formation of circular intermediate was assayed using qPCR. Results are displayed as Xfold expression. All data were standardized by simultaneous qPCR analysis of $a c p P$ expression and error bars represent standard error of the mean of three experimental replicates. *above bars indicate a significant difference compared to the control at $p<0.05$ assessed by ANOVA and Student's t-test. a; sodium hydrosulfide $(\mathrm{NaSH}), \mathrm{b}$; sodium sulfide $\left(\mathrm{Na}_{2} \mathrm{~S}\right) \mathrm{C}$; AP39. $n=3$ a

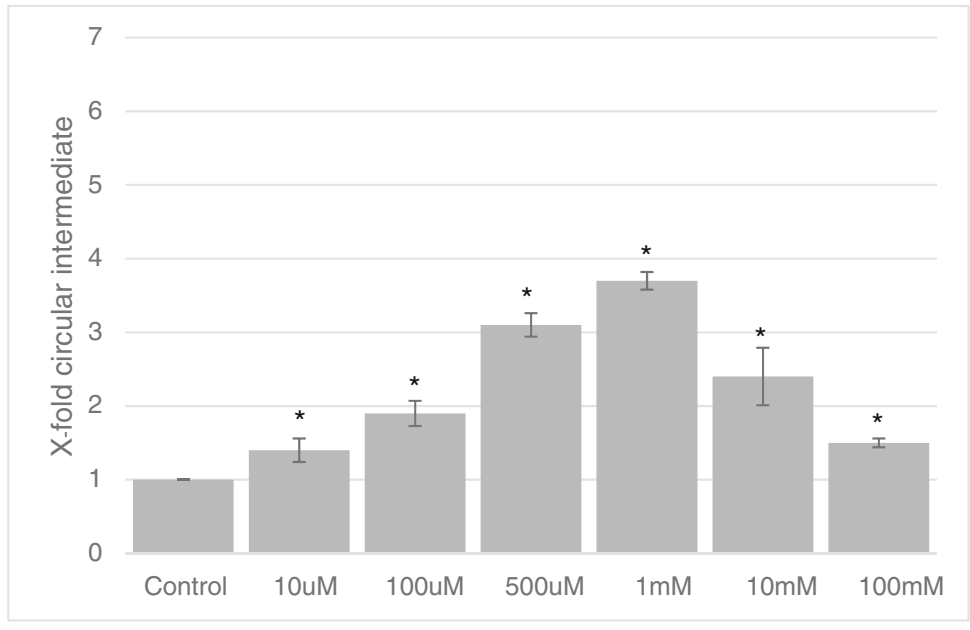

b

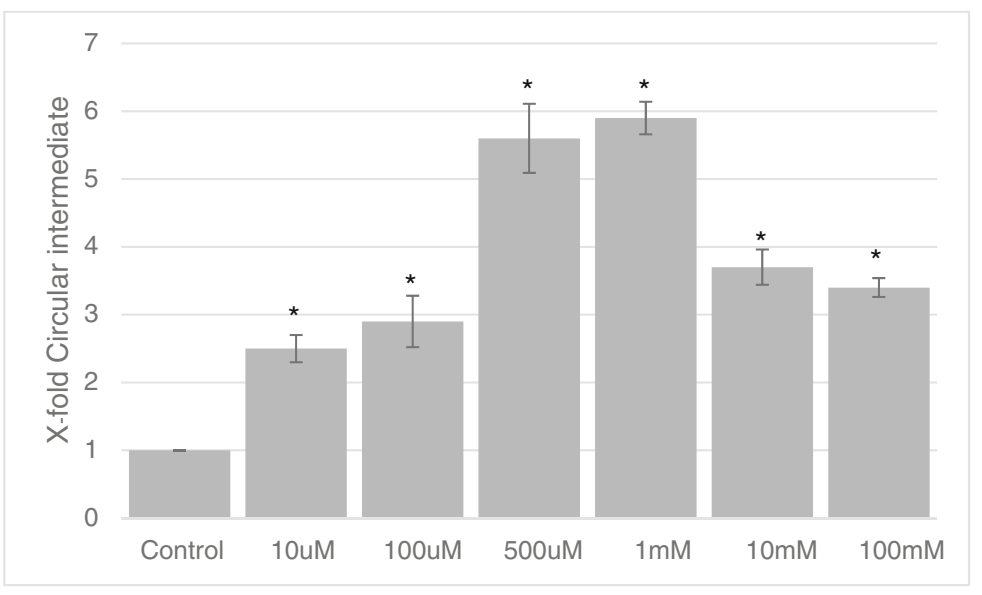

C

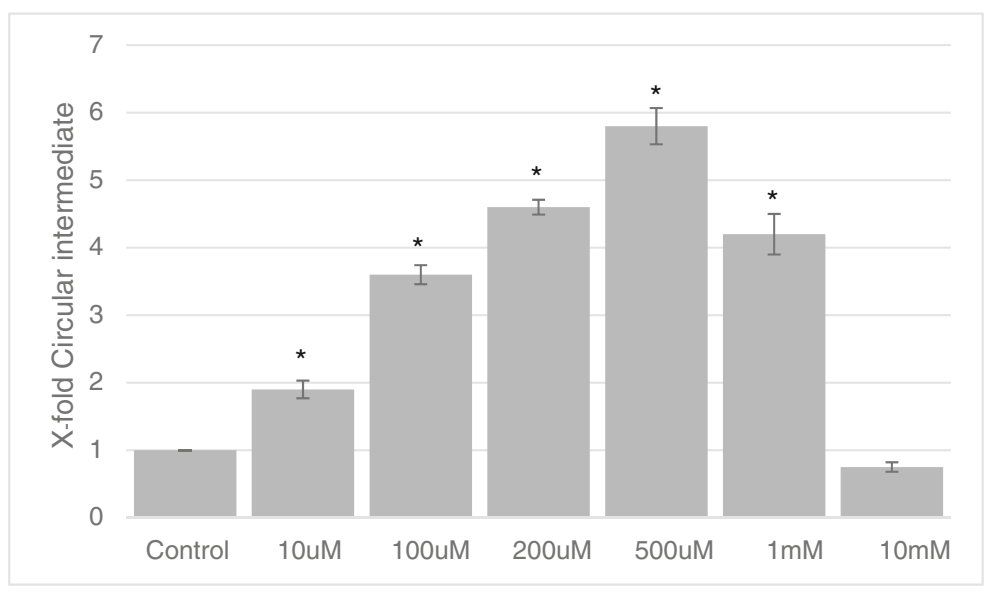

concentrations had less of an effect. Similar data were obtained with $\mathrm{NaSH}$ and $\mathrm{Na}_{2} \mathrm{~S}$ as donor molecules (data not shown), indicating that longer exposure to the $\mathrm{H}_{2} \mathrm{~S}$ had little further effect. 
Fig. 4 xer $C$ expression and circular intermediate production in Pseudomonas syringae pv. phaseolicola (Pph) 1302A following $5 \mathrm{~h}$ treatment with AP39. Pph 1302A was treated with the $\mathrm{H}_{2} \mathrm{~S}$ donor AP39 for five hours at the concentrations indicated, after which the $x e r C$ expression (a) and circular intermediate (b) were assayed using qPCR. Results are displayed as X-fold expression. All data were standardized by simultaneous qPCR analysis of $a c p P$ expression and error bars represent standard error of the mean of three experimental replicates. $n=3$. *above bars indicate a significant difference compared to the control at $p<0.05$ assessed by ANOVA and Student's t-test a

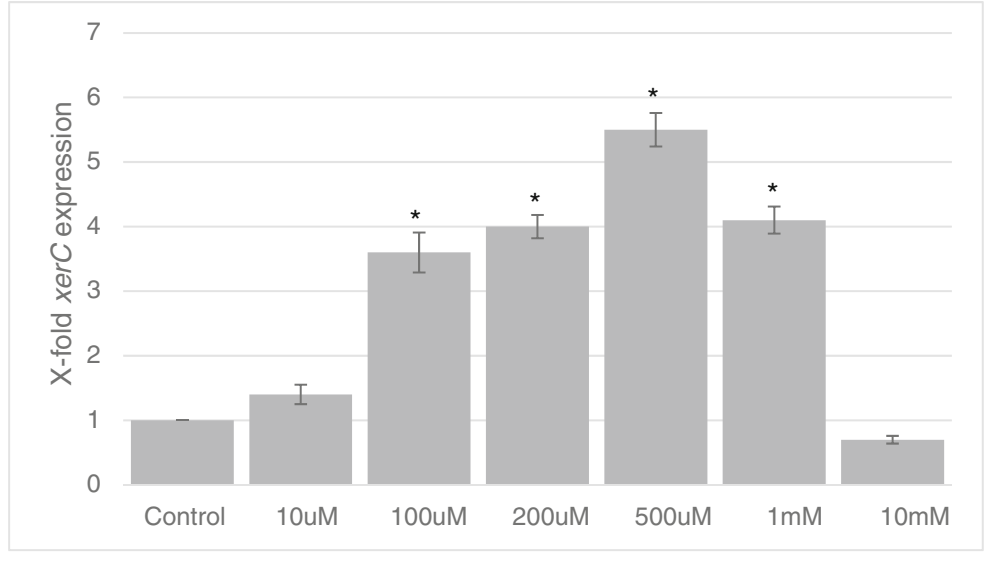

b

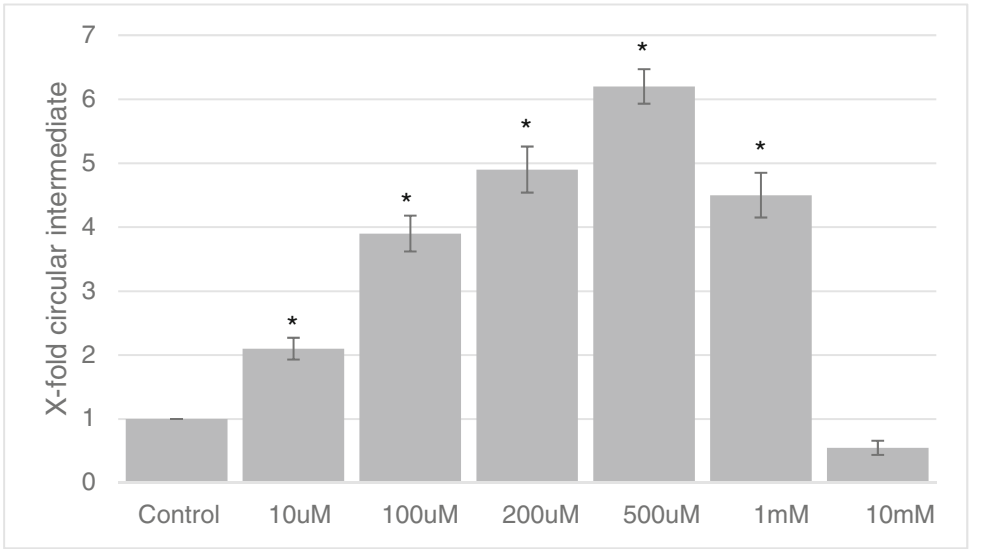

\section{Discussion}

Plant pathogens will be successful at causing disease if they can invade the tissues of the plant and overcome the plant's defences. Bacteria such as Pph produce effector molecules that may be recognised by the plant, often resulting in a defence known as the HR (Bashir et al. 2013). However, bacterial genomes are dynamic and change in response to different environments. For example, exposure of $P p h$ to the HR of the plant can trigger the loss of a large region of the bacterial genome known as PPHGI-1 (Pitman et al. 2005). This GI carries an effector gene that triggers the HR but forms a circular intermediate that can be lost from the bacterial cell and therefore allow the pathogen to cause disease. Therefore, the genomic content of the bacteria is fluid, allowing these pathogens to lose or gain DNA and the functionality that that may carry.
The elements of the plant defences which may trigger the loss of GIs from bacteria are not well understood. However, it is known that plants will produce a range of reactive molecules when challenged with a pathogen. These include reactive oxygen species (ROS: O'Brien et al. 2012) such as hydrogen peroxide, nitric oxide (NO: Bellin et al. 2013) and hydrogen sulfide $\left(\mathrm{H}_{2} \mathrm{~S}\right.$ : Calderwood and Kopriva 2014). Such molecules are used as signalling components in plants, often interacting together resulting in a coordinated response (Hancock and Whiteman 2014, 2015). Such signalling may lead to the initiation of the HR in plants and so the cessation of the pathogen progression into the plant. It can be seen therefore that invading plant pathogens are going to be subjected to the presence of a range of toxic compounds. However, such compounds may not just be plant derived. Bacteria too can produce $\mathrm{H}_{2} \mathrm{~S}$ (Clarke 1953). Therefore, it is important to understand the effects of such compounds on plant pathogens. 
In the current study, the effects of a range of $\mathrm{H}_{2} \mathrm{~S}$ donor molecules were tested to assess their effects on the growth of a well-studied plant pathogen, $P p h$ 1302A (Arnold et al. 2011). The donors here were $\mathrm{NaSH}, \mathrm{Na}_{2} \mathrm{~S}$ and AP39. The characteristics of the release of the $\mathrm{H}_{2} \mathrm{~S}$ from these compounds needs to be considered. Both $\mathrm{NaSH}$ and $\mathrm{Na}_{2} \mathrm{~S}$ are relatively unstable and will release $\mathrm{H}_{2} \mathrm{~S}$ very quickly; it is an instant $\mathrm{pH}$-dependent dissociation. Furthermore, $\mathrm{H}_{2} \mathrm{~S}$ is only slightly soluble in water and will rapidly enter the gas phase and be lost to the atmosphere. Therefore to overcome this other compounds have been developed that release $\mathrm{H}_{2} \mathrm{~S}$ over a more physiological time period. One such compound is GYY4137 ( $\mathrm{Li}$ et al. 2013) which releases $\mathrm{H}_{2} \mathrm{~S}$ much more slowly over a longer period of time and has been shown to have effects in both animals ( $\mathrm{Li}$ et al. 2013) and plants (Lisjak et al. 2010). A more recent development is a $\mathrm{H}_{2} \mathrm{~S}$ releasing compound designed to be targeted to the mitochondria of eukaryotic cells, that is, AP39. However, with the similarities between mitochondria and bacteria (Gray 2012) it is conceivable that AP39 would have effects in bacteria mediated by its capacity to release $\mathrm{H}_{2} \mathrm{~S}$.

Interestingly there was little effect of $\mathrm{NaSH}$ or AP39 on the growth of Pph unless treated at very high concentrations, at which point both appeared to be toxic. However, some bacteria, for example E. coli, have been seen to be resistant to $\mathrm{H}_{2} \mathrm{~S}$ (Forte et al. 2016), seemingly being able to maintain respiration through the use of a cytochrome oxidase $b d$ complex. $\mathrm{Na}_{2} \mathrm{~S}$ had more of an effect on Pph 1302A at lower concentrations although its kinetics of release of $\mathrm{H}_{2} \mathrm{~S}$ would be expected to be the same as that of $\mathrm{NaSH}$.

On the other hand, it may be expected that low concentrations of $\mathrm{H}_{2} \mathrm{~S}$ would promote growth, although here no evidence of that is seen (Fig. 1). $\mathrm{H}_{2} \mathrm{~S}$ is a source of sulfur for many organisms while it has been shown that many bacteria can partake in sulfur metabolism (Friedrich et al. 2001), including Pseudomonads (Friedrich and Mitrenga 1981). For mitochondria it has also been shown that $\mathrm{H}_{2} \mathrm{~S}$ can be a source of reducing equivalents (Bouillaud et al. 2013). Therefore increased growth at low, sub-lethal concentrations of $\mathrm{H}_{2} \mathrm{~S}$ may be possible in a range of organisms, both prokaryote and eukaryote.

It is now well established that bacteria such as Pph can lose GIs and other mobile elements if exposed to the plant environment during the HR. PPHGI-1 is lost from Pph1302A for example (Pitman et al. 2005), with the conditions to which the bacteria are exposed during the HR appearing to favour those individuals which lack the avirulence gene avrPphB (Pitman et al. 2005; Arnold et al. 2007; Lovell et al. 2011). Loss of PPHGI is proceeded by excision of the island from the chromosome and the formation of a circular intermediate. Excision, as measured by xerC expression and circular intermediate formation can be assayed by PCRbased methods or by the use of fluorescent tags (Godfrey et al. 2010). Here, all the $\mathrm{H}_{2} \mathrm{~S}$ donors used led to an increase in xerC expression and the formation of the circular intermediate indicative of the sulfide gas mediating island excision. Effects were seen at concentrations of $\mathrm{H}_{2} \mathrm{~S}$ donors, not affecting bacterial growth although higher concentrations of $\mathrm{H}_{2} \mathrm{~S}$ did show reduced GI loss. Interestingly, longer exposure $(5 \mathrm{~h})$ to the $\mathrm{H}_{2} \mathrm{~S}$ donors did not have a larger effect. This may be due the labile nature of the donors and loss of $\mathrm{H}_{2} \mathrm{~S}$ to the atmosphere during the assay. The effects of the $\mathrm{H}_{2} \mathrm{~S}$ appear to have driven the $\mathrm{GI}$ excision to start, but continued exposure to $\mathrm{H}_{2} \mathrm{~S}$ may not be required for the process to be taken to completion. Therefore, in planta, bacteria exposed to $\mathrm{H}_{2} \mathrm{~S}$ generated during the $\mathrm{HR}$ are also likely to be driven to undergo such genetic changes.

In conclusion, exposure of plant pathogenic bacteria such as Pph to $\mathrm{H}_{2} \mathrm{~S}$, to which such bacteria may be exposed during the process of plant invasion, will not have their growth restricted. However, they may be driven to undergo genetic modifications which will increase their propensity to cause disease in the plant. Therefore understanding the role of triggers, such as $\mathrm{H}_{2} \mathrm{~S}$, to bacterial genetic changes is important to ascertain and may be a way to modulate plant-pathogen interactions in the future. Lastly, GIs in pathogens are not restricted to plants, but are also found in animal pathogens (Wei and Guo 2011). Furthermore, $\mathrm{H}_{2} \mathrm{~S}$ has been implicated in the mechanisms by which bacteria can be resistant to antibiotics (Shatalin et al. 2011). Therefore a full understanding of how bacteria respond to, and have effects mediated by, $\mathrm{H}_{2} \mathrm{~S}$ is important to obtain and may have future implications for diseases in both animals and plants.

Acknowledgments We would like to thank the University of the West of England, Bristol for financial support for this work. This work was carried out under the Department for Environment, Food and Rural Affairs' Plant Health and Seeds Inspectorate license number 51049/202078/1. 
Open Access This article is distributed under the terms of the Creative Commons Attribution 4.0 International License (http:// creativecommons.org/licenses/by/4.0/), which permits unrestricted use, distribution, and reproduction in any medium, provided you give appropriate credit to the original author(s) and the source, provide a link to the Creative Commons license, and indicate if changes were made.

\section{References}

Alvarez, C., Calo, L., Romero, L. C., Garcia, I., \& Gotor, C. (2010). An $O$-acetylserine(thiol)lyase homolog with Lcysteine desulfhydrase activity regulates cysteine homeostasis in Arabidopsis. Plant Physiology, 152, 656-669.

Arnold, D. L., Jackson, R. W., Waterfield, N. R., \& Mansfield, J. W. (2007). Evolution of microbial virulence: The benefits of stress. Trends in Genetics, 23, 293-300.

Arnold, D. L., Lovell, H. C., Jackson, R. W., \& Mansfield, J. W. (2011). Pseudomonas syringae pv. Phaseolicola: From 'has bean' to supermodel. Molecular Plant Pathology, 12(7), 617-627.

Bashir, Z., Ahmad, A., Shafique, S., Anjum, T., Shafique, S., \& Akram, W. (2013). Hypersensitive response - A biophysical phenomenon of producers. European Journal of Microbiology and Immunology, 3, 105-110.

Bellin, D., Asai, S., Delledonne, M., \& Yoshioka, H. (2013). Nitric oxide as a mediator for defense responses. Molecular Plant Microbe Interactions, 26, 271-277.

Bouillaud, F., Ransy, C., \& Andriamihaja, M. (2013). Sulfide and mitochondrial bioenergetics. Nitric Oxide, 31, S15.

Calderwood, A., \& Kopriva, S. (2014). Hydrogen sulfide in plants: From dissipation of excess sulfur to signaling molecule. Nitric Oxide, 41, 72-78.

Clarke, P. H. (1953). Hydrogen sulphide production by bacteria. Journal of General Microbiology, 8, 397-407.

De Kok, J. L., Bosma, W., Maas, F. M., \& Kuiper, P. J. C. (1985). The effect of short-term $\mathrm{H}_{2} \mathrm{~S}$ fumigation on water-soluble sulphydryl and glutathione levels in spinach. Plant Cell \& Environment, 8, 189-194.

Dooley, F. D., Nair, S. P., \& Ward, P. D. (2013). Increased growth and germination success in plants following hydrogen sulfide administration. PloS One, 8, e62048.

Dorman, D. C., Moulin, F. J., McManus, B. E., Mahle, K. C., James, R. A., \& Struve, M. F. (2002). Cytochrome oxidase inhibition induced by acute hydrogen sulfide inhalation: Correlation with tissue sulfide concentrations in the rat brain, liver, lung, and nasal epithelium. Toxicological Sciences, 65, 18-25.

Forte, E., Borisov, V. B., Falabella, M., Colaco, H. G., TinajeroTrejo, M., Poole, R. K., et al. (2016). The terminal oxidase cytochrome $b d$ promotes sulfide-resistant bacterial respiration and growth. Scientific Reports, 6, 23788.

Friedrich, C. G., \& Mitrenga, G. (1981). Oxidation of thiosulfate by Paracoccus denitrificans and other hydrogen bacteria. FEMS Microbiology Letters, 10, 209-212.

Friedrich, C. G., Rother, D., Bardischewsky, F., Quentmeier, A., \& Fischer, J. (2001). Oxidation of reduced inorganic sulfur compounds by bacteria: Emergence of a common mechanism? Applied and Environmental Microbiology, 67, 2873-2882.
García-Mata, C., \& Lamattina, L. (2010). Hydrogen sulfide, a novel gasotransmitter involved in guard cell signalling. New Phytologist, 188, 977-984.

Godfrey, S. A., Mansfield, J. W., Corry, D. S., Lovell, H. C., Jackson, R. W., \& Arnold, D. L. (2010). Confocal imaging of Pseudomonas syringae pv. Phaseolicola colony development in bean reveals reduced multiplication of strains containing the genomic island PPHGI-1. Molecular PlantMicrobe Interactions, 23(10), 1294-1302.

Gray, M. W. (2012). Mitochondrial evolution. Cold Spring Harbor Perspectives in Biology, 4, a011403.

Guidotti, T. L. (1996). Hydrogen suphide. Occupational Medicine, 46(5), 367-371.

Hacker, J., \& Carniel, E. (2001). Ecological fitness, genomic islands and bacterial pathogenicity. A Darwinian view of the evolution of microbes. EMBO Reports, 2, 376-381.

Hancock, J. T., \& Whiteman, M. (2014). Hydrogen sulfide and cell signaling: Team player or referee? Plant Physiology and Biochemistry, 78, 37-42.

Hancock, J. T., \& Whiteman, M. (2015). Hydrogen sulfide signaling: Interactions with nitric oxide and reactive oxygen species. Annals of the New York Academy of Sciences. doi:10.1111/nyas.12733.

Juhas, M., van der Meer, J. R., Gaillard, M., Harding, R. M., Hood, D. W., \& Crook, D. W. (2009). Genomic islands: Tools of bacterial horizontal gene transfer and evolution. FEMS Microbiology Reviews, 33, 376-393.

Le Trionnaire, S., Perry, A., Szczesny, B., Szabo, C., Winyard, P. G., Whatmore, J., et al. (2014). The synthesis and functional evaluation of a mitochondria-targeted hydrogen sulfide donor, (10-oxo-10-(4-(3-thioxo-3H-1,2-dithiol-5-yl) phenoxy)decyl)triphenylphosphonium bromide (AP39). Medicinal Chemistry Communications, 5, 728-736.

Li, L., Fox, B., Keeble, J., Salto-Tellez, M., Winyard, P. G., Wood, M. E., et al. (2013). The complex effects of the slow-releasing hydrogen sulphide donor GYY4137 in a model of acute joint inflammation and in human cartilage cells. Journal of Cellular and Molecular Medicine, 17, 365-376.

Lisjak, M., Srivastava, N., Teklic, T., Civale, L., Lewandowski, K., Wilson, I., et al. (2010). A novel hydrogen sulfide donor causes stomatal opening and reduces nitric oxide accumulation. Plant Physiology and Biochemistry, 48, 931-935.

Lisjak, M., Teklic, T., Wilson, I. D., Wood, M., Whiteman, M., \& Hancock, J. T. (2011). Hydrogen sulfide effects on stomatal apertures. Plant Signaling and Behavior, 6, 1444-1446.

Lisjak, M., Teklic, T., Wilson, I. D., Whiteman, M., \& Hancock, J. T. (2013). Hydrogen sulfide: Environmental factor or signaling molecule? Plant Cell \& Environment, 36, 1607-1616.

Lovell, H. C., Mansfield, J. W., Godfrey, S. A., Jackson, R. W., Hancock, J. T., \& Arnold, D. L. (2009). Bacterial evolution by genomic island transfer occurs via DNA transformation in planta. Current Biology, 19(18), 1586-1590.

Lovell, H. C., Jackson, R. W., Mansfield, J. W., Godfrey, S., Hancock, J. T., Desikan, R., et al. (2011). In planta conditions induce genomic changes in Pseudomonas syringae $p v$. Phaseolicola. Molecular Plant Pathology, 12, 167-176.

Martin, W., Baross, J., Kelley, D., \& Russell, M. J. (2008). Hydrothermal vents and the origin of life. Nature Reviews Microbiology, 6, 805-814. 
Morse, J. W., Millero, F. J., Cornwell, J. C., \& Rickard, D. (1987). The chemistry of the hydrogen sulfide and iron sulfide systems in natural waters. Earth-Science Reviews, 24, 1-42.

O’Brien, J. A., Daudi, A., Butt, V. S., \& Bolwell, G. P. (2012). Reactive oxygen species and their role in plant defence and cell wall metabolism. Planta, 236, 765-779.

O'Leary, B. M., Neale, H. C., Geilfus, C.-M., Jackson, R. W., Arnold, D. L., \& Preston, G. M. (2016). Early changes in apoplast composition associated with defence and disease in interactions between Phaseolus vulgaris and the halo blight pathogen Pseudomonas syringae $P v$. phaseolicola. Plant, Cell and Environment, 39, 21722184.

Petriccione, M., Salzano, A. M., Di Cecco, I., Scaloni, A., \& Scortichini, M. (2014). Proteomic analysis of the Actinidia deliciosa leaf apoplast during biotrophic colonization by Pseudomonas syringe pv. actinidiae. Journal of Proteomics, 101, 43-62.

Pitman, A. R., Jackson, R. W., Mansfield, J. W., Kaitell, V., Thwaites, R., \& Arnold, D. A. (2005). Exposure to host resistance mechanisms drives the evolution of virulence in plants. Current Biology, 15, 2230-2235.

Rico, A., \& Preston, G. M. (2008). Pseudomonas syringe pv. tomato DC3000 uses constitutive and apoplast-induced nutrient assimilation pathways to catabolize nutrients that are abundant in the tomato apoplast. Molecular Plant-Microbe Interactions, 21, 269-282.
Shatalin, K., Shatalina, E., Mironov, A., \& Nudler, E. (2011). $\mathrm{H}_{2} \mathrm{~S}$ : A universal defense against antibiotics in bacteria. Science, $334,986$.

Szczesny, B., Módis, K., Yanagi, K., Coletta, C., Le Trionnaire, S., Perry, A., et al. (2014). AP39, a novel mitochondria-targeted hydrogen sulfide donor, stimulates cellular bioenergetics, exerts cytoprotective effects and protects against the loss of mitochondrial DNA integrity in oxidatively stressed endothelial cells in vitro. Nitric Oxide, 15, 120-130.

Taylor, J. D., Teverson, D. M., Allen, D. J., \& Pastor-Corrales, M. A. (1996). Identification and origin of races of Pseudomonas syringae $P v$. Phaseolicola from Africa and other bean growing areas. Plant Pathology, 45, 469-478.

Wang, R. (2002). Two's company, three's a crowd: $\mathrm{Can} \mathrm{H}_{2} \mathrm{~S}$ be the third endogenous gaseous transmitter? FASEB Journal, 16, 1792-1798.

Wang, R. (2003). The gasotransmitter role of hydrogen sulfide. Antioxidants \& Redox Signaling, 5, 493-501.

Wei, W., \& Guo, F. B. (2011). Prediction of genomic islands in seven human pathogens using the Z-island method. Genetics and Molecular Research, 10, 2307-2315.

Wilson, L. G., Bressan, R. A., \& Filner, P. (1978). Light-dependent emission of hydrogen sulfide from plants. Plant Physiology, 61, 184-189.

Zhao, Y., Biggs, T. D., \& Xian, M. (2014). Hydrogen sulfide $\left(\mathrm{H}_{2} \mathrm{~S}\right)$ releasing agents: Chemistry and biological applications. Chemical Communications, 50, 11788-11805. 